\title{
Systematic Review on Executive Functions in Children with Poor Motor Skills and With Development Coordination Disorder
}

\author{
RF Sartori ${ }^{1 *}$, N. CValentini ${ }^{2}$, GC Nobre ${ }^{3}$ and RP Fonseca ${ }^{4}$ \\ ${ }^{1}$ Department of Physical Education at the Pontifical Catholic University of Rio Grande do Sul and Serra Gaucha University, Brazil \\ ${ }^{2}$ Department of Physical Education, School of Physical Education, Physiotherapy and Dance, Federal University of Rio Grande do Sul, Porto \\ Alegre, Rio Grande do Sul, Brazil
}

${ }^{3}$ Department of physical Education, Federal Institute of Education, Science and Technology of Ceará, Fortaleza, Brazil

${ }^{4}$ Pontifical Catholic University of Rio Grande do Sul Rio Grande do Sul, Brazil

*Corresponding author: RF Sartori, Department of Physical Education at the Pontifical Catholic University of Rio Grande do Sul, Brazil

\begin{abstract}
Objective: The aim of this study was to describe the tests used to assess working memory, inhibition, and cognitive flexibility, and analyzed the main research results related to executive functions in children with Developmental Coordination Disorder or with poor motor skills. Methods: This review used as data sources studies in MEDLINE, Web of Science, APA PsycNET, EMBASE, and Google Scholar with children with poor motor skills, DCD, and typical development. Quality of the studies was conducted using the Newcastle Ottawa Scale. Results: 1475 papers found, 31 matched the review criteria; 31 different executive function tests used to assess children with poor motor skills and DCD. Across the 31 studies, included in this systematic review, eleven studies examined only the working memory; ten studies measured only inhibition, a single study measured only cognitive flexibility, three studies examined the working memory and inhibition, one study examined inhibition and cognitive flexibility, one study examined working memory and cognitive flexibility and four studies examined the three executive functions. In conclusion, many tests were used to assess children with poor motor skill and DCD requiring verbal, nonverbal, or complex visuospatial processing, with or without motor demand involved. In some tests the different demands or different types of stimulus involved cause secondary loss in execution. The executive functions deficits in children with poor motor skills and DCD are in a wide ranging and extend across basic all functions assessed (working memory, inhibition, and cognitive flexibility). The pervasive and persistent nature of the executive function deficits suggests a need for a more aligned methodological approach to investigate this phenomenon.
\end{abstract}

Keywords: Working Memory; Inhibition; Cognitive Flexibility; Dcd and Poor Motor Skill

\section{Introduction}

The Developmental Coordination Disorder (DCD) can present itself in an isolated manner, with the child showing difficulties in executing motor skills [1], or associated with academic contents [2], and movement planning (Brown-Lum \& Zwicker, 2015; Zwicker et al., 2012)difficulties. Social and emotional [3], and cognitive development [4] are also affected. The close relation between motor and cognitive development is explained by cerebral areas activation, when motor control areas show neural activation during the execution of an movement certain cognitive areas are also coactivated (Diamond, 2000). Moreover, there is evidence of a specific relation between motor delays and deficits in executive functions [5].Executive functions are cognitive processes that allow the individual to direct behaviors to goals, evaluate the efficiency and adequacy of these behaviors, abandon inefficient strategies in favor of others that are more efficient, and solve immediate and long term problems [6]. Executive functions, therefore, regulate human behavior [7] by find the solution of problems, selective inhibit a behavior, control and change an action, and remember components necessary to act [8]. The executive functions are studied in three main components, the working memory (i.d. storing and updating information while the individual does some activity related to it), 
inhibitory control (i.d. inhibition of automatized response when the individual is engaged in the execution of a task), and cognitive flexibility (i.d. changing the focus of attention and cognition between dimensions related to a given task) [9].

Several times the use of tests or tasks that are highly complex cover more than one component of the executive functions depend on other cognitive abilities to be performed successfully (Leonard \& Hill, 2015; Wilson et al., 2012). Depending on the complexity of test various executive functions are measured since the tests lack purity [10]. Besides, many measurements of executive functions demand motor responses or complex visuospatial processing that may affecting the performance of children with DCD or with motor difficulties due to the poor motor skills and not necessarily to limited executive functions. The characteristics of the tests to assess executive functions and the results of assessments need to be further investigated in order to better understand the subjacent mechanisms affecting executive function in children with DCD or with motor difficulties. The aim of this study was to describe the tests used to assess working memory, inhibition, and cognitive flexibility, and analyzed the main research results related to executive functions in children with DCD or with poor motor skills.

\section{Methods}

This systematic review (registered at the international prospective register of systematic reviews PROSPERO network - http://www.crd.york.ac.uk/prospero/: Registration CRD42016047299) was conducted using the Preferred Reporting Items for Systematic Reviews and Meta-Analyses (PRISMA) (Moher, Liberati, Tetzlaff, \& Altman, 2009).All the original studies investigating executive function in children and adolescents with DCD or poor motor skills were eligible. We used the acronyms PECOT (Population, Exposure, Comparing, Outcome and Type of study) in accordance with the PRISMA protocol as an auxiliary method for the inclusion of studies. Therefore, we included studies with: (P) Population of children and adolescents, from 5 to 16 years old, with probable DCD [11], with DCD, or poor motor skills; (E) Exposure of instruments of clinical evaluation that assess working memory, inhibition or cognitive flexibility [12]; (0) Outcome that measure executive functions capacity;(T) Type of study included observational, intervention, and peer reviewed studies.

The MEDLINE (accessed by PubMed), Web of Science, APA PsycNET, EMBASE and Google Scholar databases were search, until December of the 2018. We used specific descriptors, Boolean operators (AND \& OR), and specific keywords for working memory ("working memory"[All Fields] OR "visuospatial working memory"[All Fields] OR "verbal working memory"[All Fields]), inhibition("Inhibitory control"[All Fields] OR "inhibitory function"[All Fields] OR "Response inhibition"[All Fields] OR "Inhibitory controls"[All Fields] OR "inhibition"[All Fields]), and cognitive flexibility("cognitive flexibility"[All Fields] OR "Flexible cognition"[All Fields] OR "Shifting"[All Fields] OR "Set-shifting"[All Fields] OR "mental flexibility"[All Fields]). Executive functions were associated with keywords regarding the motor skills difficulties ("Developmental Coordination Disorder"[All Fields] OR "Motor Disorder"[All Fields] OR “DCD”[All Fields] OR “Dyspraxia”[All Fields] OR "Motor Skill Disorder" OR "poor motor skill” [All Fields]);none filters were used. We extracted categories for background (aim of the study and construct or domain of the executive function), methods (instruments or procedures for assessing the executive function, samples age,sex,number of participants with and without DCD, motor tests and cut off points used; confounding factors), and main findings and other relevant information reported by studies.

\section{Assessment of Study Quality}

The quality of the studies was assessed using the Newcastle/ Ottawa Scale (NOS: Takahashi \& Hashizume, 2014);each study was evaluated using the point system. Two authors did a critical evaluation of the included studies for potential sources of bias (selection bias, detection bias, reporting bias, performance bias, attrition bias), methods of participant allocation and allocation concealment, and blind assessment. Study design was assessed regarding selection (representativeness of the sample, sample size, description of groups, ascertainment of exposure), confound comparability (based on design and analysis), and outcome (assessment of outcome and statistical test) considering recognize cut offs points, maximum score of five for cross-sectional studies ( 5 = very good; 4 = good; 3 = satisfactory; $0-2=$ unsatisfactory) and eight for cohort studies (7-8 = very good; $5-6$ = good; 4 = satisfactory; $0-3=$ unsatisfactory). The two raters achieved consensus through discussion ( $\mathrm{K}=0.90)$; the third author settled discrepant results.

\section{Results}

In the selection process, we identified 1475 papers using title and abstract screening; 31 matched review criteria. Approximately $90.3 \%$ ( $\mathrm{n}=28$ studies) were conducted within the last 10 years. In addition, 33 different tests to assess executive function were found within 31 studies. Sample sizes, including children with DCD or poor motor skills, ranged from 11 to 71 participants from England, Germany, Australia, Italy, Canada, France, Finland, Taiwan, and US. Figure 1 provided a selection process synthesis. 


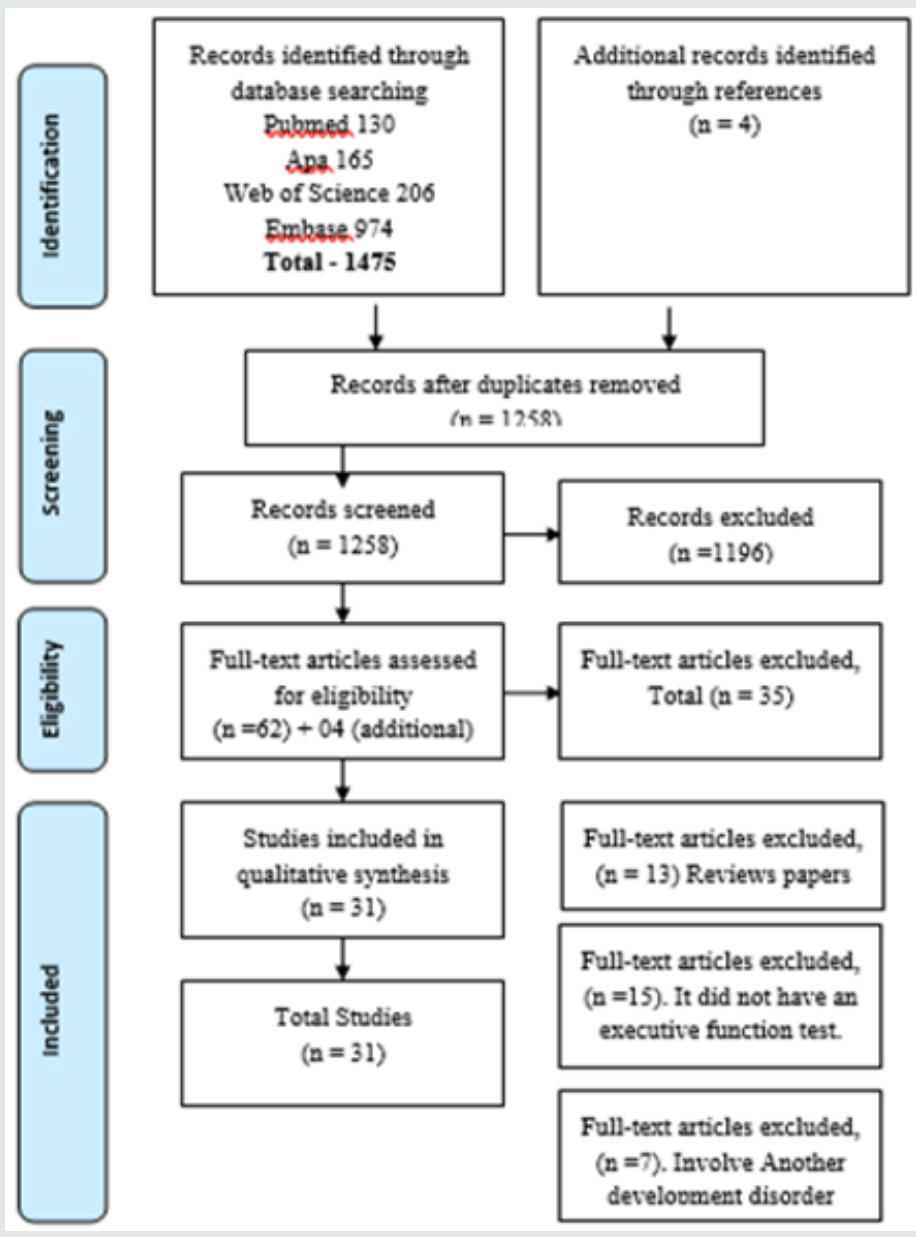

Figure 1: Flow chart of study selection.

\section{Inhibition Measurements in Children with DCD or Poor Motor Skills}

Descriptive studies were first conducted, regarding inhibition and motor development, using the Simon Task [13].Latter on, the Go/no-Go test [14], the Stop-Signal Task and Day/Night Stroop tests (Livesey, Keen, Rouse, \& White, 2006; Pratt et al., 2014), and the Verbal -Motor Inhibition tests [15] were used with the same objective. Yet, the Covert Orienting of Visuospatial Attention Task (COVAT) were used to investigate the associations spatial attention and motor difficulties [16]. The Go/no-Go test and neuroimaging was used to investigate the neural processes of inhibitory control in children with DCD [17]; and also in a experimental study investigating the impact of a neutral or positive reinforcement in inhibitory control of children with DCD [18]. And finally, Animal Stroop Task was used to compare results between children at risk for DCD and typical children [19].

Regarding intervention studies, two were conducted for children with DCD using Posner Paradigm to investigate changes in inhibition [20]; the visuospatial selective attention paradigm provides a measurement of conflict resolution that has been acknowledge as a trustworthy index of inhibitory control [21]. Two follow-up studies conducted during one-year [22] and two-years [23], assessed inhibitory control in children with and without motor difficulties using the Fruit Stroop Task test; and another studied conducted in England used the Verbal and Motor Inhibition tests to assess association of inhibition, poor motor skills and academic achievement in two-years follow-up study [24].

\section{Working Memory Measurements in Children with DCD or Poor Motor Skills}

Regarding to descriptive studies, working memory has been investigate in children with DCD in relation to the proficiency of motor skills using the Trail Making Test [25] the N-Back task $[26,27]$; and the Automated Working Memory Assessment [28]. Yet, a study investigated the visuospatial working memory mechanisms using the Visuospatial Working Memory Paradigm (VSWM) and compared the brain activity (electroencephalography) of typical and atypical children [29]; and the relation between motor coordination and visuospatial working memory in children with DCD, was investigated using the Cog State One-Back [30]. To verify attention and working memory in children with poor motor skills, the Cambridge Neuropsychological Test Automated Battery was used [31]. To compare results between children at risk for DCD and TD children three verbal and three visuospatial tasks were used [32].

A study conducted in England [33] investigate several executive functions in children with poor motor skills and DCD, using the Working Memory Battery for Children [34] to assess verbal 
working memory and the Odd-One-Out test [35] for the nonverbal working memory. Yet, a studied conducted in Italy using the Motor Observation Questionnaire for Teachers to investigate the relation between the poor motor skills and visuospatial working memory in children with DCD [36]. Regarding to a follow-up studies, a one-year [37] and two- years [38] studies assessed visuospatial working memory using the Backwards Color Recall task and the Corsi-Blocks Backwards tests. And another follow-up study used the Working Memory Battery for Children and Odd-One-Out in children with poor motor skills and DCD children over 2 years [38].

\section{Cognitive Flexibility Measurements in Children with DCD or Poor Motor Skills}

Deficits in cognitive flexibility tasks were assessed in children with DCD using an Inspection Time Task in an Australian study
[39]. The Wisconsin Card Sorting test [40] and the Wisconsin Card Sorting Test has been developed to assess reasoning and the ability of changing cognitive strategies in response to environmental changes. Regarding to follow-up studies, in a one-year study the Cognitive Flexibility Test was used [41] and in a two-years period the Flanker Task [42] were used to assess cognitive flexibility in children with DCD. Another study conducted in France used the Trail Making Test [43] to compare the development of cognitive flexibility in children with motor difficulties. And the Intra-Extra Dimensional Test Set Shift to follow-up changes in nonverbal cognitive flexibility of the children over 2-years period [44]. Table 1 provided the main results of the testes used to measure executive functions in children with poor motor skill and DCD. Table 1 describes the tests and outcomes in studies design to assess executive functions in children.

Table 1: Description of tools (tests/tasks) and outcome variables administered to assess executive functions (Inhibition, working memory and cognitive flexibility) in children with DCD and/or poor motor skills.

\begin{tabular}{|c|c|c|c|c|c|}
\hline Code & Autor/Year & $\begin{array}{l}\text { Executive } \\
\text { function } \\
\text { measured }\end{array}$ & Tests/task & Description of the test/task & $\begin{array}{l}\text { Outcome } \\
\text { Variables }\end{array}$ \\
\hline 2-Jan & $\begin{array}{l}\text { (Mandich; } \\
\text { Buckolz; } \\
\text { Polatajko, 2002, } \\
\text { 2003) }\end{array}$ & Inhibition & Simon task & $\begin{array}{l}\text { The participant is told that they should press the button on } \\
\text { the right when they see something red appear on the screen, } \\
\text { and the button on the left when they see something green. } \\
\text { Participants are usually told to ignore the location of the } \\
\text { stimulus and base their response on the task-relevant color. }\end{array}$ & $\begin{array}{l}\text { Reaction times } \\
\text { and errors }\end{array}$ \\
\hline 3 & $\begin{array}{l}\text { (PiekEt Al., } \\
\text { 2004) }\end{array}$ & $\begin{array}{l}\text { Working } \\
\text { memory; } \\
\text { Inhibition }\end{array}$ & $\begin{array}{l}\text { Trail Making Test } \\
\text { Go/No-Go Task } \\
\text { (GNG) }\end{array}$ & $\begin{array}{l}\text { This task consists of the presentation of a target set (i.e. the } \\
\text { letters A, B, C, and D), with the actual target presented being } \\
\text { an ordered rotation of these four letters. Participants must } \\
\text { differentiate if: (1) the letter presented on the computer } \\
\text { screen is a member of the target set (i.e. A, B, C, or D) and (2) } \\
\text { if it is the current target. } \\
\text { Some letters are designated as 'Go' or 'No-go' and are } \\
\text { displayed in 1s intervals. When a Go stimulus is presented } \\
\text { it is necessary to press a button and inhibit when a new } \\
\text { stimulus is presented. }\end{array}$ & $\begin{array}{c}\text { Mean time/ } \\
\text { number correct } \\
\text { answers }\end{array}$ \\
\hline 4 & $\begin{array}{l}\text { (LiveseyEt Al., } \\
\text { 2006) }\end{array}$ & Inhibition & $\begin{array}{l}\text { The stop-signal } \\
\text { task (SST) } \\
\text { Day-night Stroop } \\
\quad \text { task }\end{array}$ & $\begin{array}{l}\text { The participant must respond to a stimulus (represented by } \\
\text { arrows) by touching either of the two options depending on } \\
\text { the direction in which the arrow points point Four pairs of } \\
\text { stimuli presented to children (day / night, boy / girl, large / } \\
\text { small and up / down). The children were directed to say the } \\
\text { opposite of the presented stimulus. }\end{array}$ & $\begin{array}{l}\text { Reaction times } \\
\text { and response } \\
\text { accuracy } \\
\text { Total errors }\end{array}$ \\
\hline $5 / 6 / 7 / 8$ e 9 & $\begin{array}{c}\text { (Alloway, } \\
\text { Gnanathusharan, } \\
\text { \& Archibald, } \\
\text { 2009; Alloway } \\
\text { \& Archibald, } \\
\text { 2008; Alloway } \\
\text { \& Temple, 2007; } \\
\text { Alloway, 2007, } \\
\text { 2011) }\end{array}$ & $\begin{array}{l}\text { Working } \\
\text { memory }\end{array}$ & $\begin{array}{l}\text { Automated } \\
\text { Working Memory } \\
\text { Assessment - } \\
\text { AWMA }\end{array}$ & $\begin{array}{l}\text { Verbal and visuo-spatial working memory were measured } \\
\text { using tasks involving simultaneous storage and processing of } \\
\text { information. One example of a verbal working memory task } \\
\text { is counting recall, in which the participant counts the number } \\
\text { of target items in each of a series of successive arrays and } \\
\text { then recalls the totals for each array in the original sequence. } \\
\text { Visuo-spatial working memory tasks include rotating images } \\
\text { and recalling their locations. }\end{array}$ & $\begin{array}{l}\text { Total correct } \\
\text { trials. }\end{array}$ \\
\hline 10 & $\begin{array}{l}\text { (PiekEt Al., } \\
\text { 2007) }\end{array}$ & $\begin{array}{l}\text { Working } \\
\text { memory } \\
\text { Cognitive } \\
\text { Flexibility }\end{array}$ & $\begin{array}{l}\text { Trail making test } \\
\text { for updating; } \\
\text { Inspection time } \\
\text { task }\end{array}$ & $\begin{array}{l}\text { This task consists of the presentation of a target set (i.e. the } \\
\text { letters A, B, C, and D), with the actual target presented being } \\
\text { an ordered rotation of these four letters. Participants must } \\
\text { differentiate if: (1) the letter presented on the computer } \\
\text { screen is a member of the target set (i.e. A, B, C, or D) and } \\
\text { (2) if it is the current target. This is a task where the length } \\
\text { of a line is discriminated, and the time of visual inspection is } \\
\text { checked to correctly discriminate a type of stimulus. }\end{array}$ & $\begin{array}{l}\text { Mean time/ } \\
\text { number correct } \\
\text { answers Mean } \\
\text { time/ number } \\
\text { correct answers }\end{array}$ \\
\hline 11 & $\begin{array}{l}\text { (Querneet al., } \\
\text { 2008) }\end{array}$ & Inhibition & Go/No-Go Task & $\begin{array}{l}\text { The task requested of participants was to press a reply key } \\
\text { to any letter presented sequentially (Go), except X (No-go). } \\
\text { According to Casey et al. (1997), its design allows to isolate } \\
\text { the brain regions involved in the suppression of the motor } \\
\text { response (Go-No-go) }\end{array}$ & Total errors \\
\hline
\end{tabular}




\begin{tabular}{|c|c|c|c|c|c|}
\hline 12 & (Tsai, 2009) & Inhibition & $\begin{array}{l}\text { Posner-paradigm } \\
\text { protocols }\end{array}$ & $\begin{array}{l}\text { Children are seated in front of a computer screen situated } \\
\text { at eye level. They are instructed to fixate at a central point } \\
\text { on the screen, marked by a dot or cross. To the left and the } \\
\text { right of the point are two boxes. For a brief period, a cue is } \\
\text { presented on the screen. Following a brief interval after the } \\
\text { cue is removed, a target stimulus, usually a shape, appears in } \\
\text { either the left or right box. The observer must respond to the } \\
\text { target immediately after detecting it. }\end{array}$ & $\begin{array}{l}\text { Reaction times } \\
\text { and response } \\
\text { accuracy }\end{array}$ \\
\hline 13 & $\begin{array}{l}\text { (Dyck; Piek, } \\
\text { 2010b) }\end{array}$ & $\begin{array}{l}\text { Working } \\
\text { memory; } \\
\text { Inhibition }\end{array}$ & $\begin{array}{l}\text { Trail Making Test } \\
\text { Go/no go task. }\end{array}$ & $\begin{array}{l}\text { This task consists of the presentation of a target set (i.e. the } \\
\text { letters A, B, C, and D), with the actual target presented being } \\
\text { an ordered rotation of these four letters. Participants must } \\
\text { differentiate if: (1) the letter presented on the computer } \\
\text { screen is a member of the target set (i.e. A, B, C, or D) and } \\
\text { (2) if it is the current target. Some letters are designated as } \\
\text { 'Go' or 'No-go and are displayed in 1s intervals. When a Go } \\
\text { stimulus is presented it is necessary to press a button and } \\
\text { inhibit when a new stimulus is presented. }\end{array}$ & $\begin{array}{l}\text { Times and } \\
\text { response } \\
\text { accuracy Total } \\
\text { errors and } \\
\text { omissions }\end{array}$ \\
\hline 14 & $\begin{array}{l}\text { (Michelet al., } \\
\text { 2011) }\end{array}$ & $\begin{array}{l}\text { Cognitive } \\
\text { Flexibility } \\
\text { Working } \\
\text { memory } \\
\text { Inhibition }\end{array}$ & $\begin{array}{l}\text { Cognitive } \\
\text { Flexibility Test } \\
\text { Backwards Color } \\
\quad \text { Recall task } \\
\text { Fruit Stroop task }\end{array}$ & $\begin{array}{l}\text { Children are informed that their task is to feed two families of } \\
\text { fish consecutively. They must feed one member of one family } \\
\text { and one member of the other family in sequence. Each time } \\
\text { one of the two fish appeared the child must decide who it was } \\
\text { to feed instead of the previous action. } \\
\text { A sequence of colored disks was presented to the children on } \\
\text { a computer screen and the children were asked to recall the } \\
\text { sequence in reverse order. } \\
\text { It is a task with images of four different types of fruit and } \\
\text { vegetables presented so that colors are named as quickly as } \\
\text { possible in congruent or incongruent assays. }\end{array}$ & $\begin{array}{l}\text { Reaction times } \\
\text { and response } \\
\text { accuracy } \\
\text { Total correct } \\
\text { trials } \\
\text { Time and total } \\
\quad \text { errors }\end{array}$ \\
\hline 15 & $\begin{array}{l}\text { (Wuang; Su; Su, } \\
\text { 2011) }\end{array}$ & $\begin{array}{l}\text { Cognitive } \\
\text { Flexibility }\end{array}$ & $\begin{array}{l}\text { Wisconsin Card } \\
\text { Sorting Test }\end{array}$ & $\begin{array}{l}\text { Several stimulus cards are presented to the participant. The } \\
\text { participant is told to match the cards, but not how to match; } \\
\text { however, he or she is told whether a match is right or wrong. }\end{array}$ & Total errors \\
\hline 16 & $\begin{array}{l}\text { (Rigoliet al., } \\
\text { 2012c) }\end{array}$ & $\begin{array}{l}\text { Working } \\
\text { memory }\end{array}$ & N-Back Task & $\begin{array}{l}\text { The task is done from the presentation of the examinee to a } \\
\text { stimulus that must be stored, at the same time as it should } \\
\text { evoke the stimulus presented to him either a (1-back), two } \\
\text { (2-back) or three (3-back) positions. }\end{array}$ & $\begin{array}{l}\text { Total correct } \\
\quad \text { trials }\end{array}$ \\
\hline 17 & (Tsaiet al., 2012) & $\begin{array}{l}\text { Working } \\
\text { memory }\end{array}$ & $\begin{array}{l}\text { VSWM - } \\
\text { Visuospatial } \\
\text { Working Memory } \\
\text { Paradigm. } \\
\end{array}$ & $\begin{array}{l}\text { The children were asked to compare the positions and } \\
\text { directions of the ladybirds in the rectangles. In two spatial } \\
\text { memory tasks, the rectangles and ladybirds appeared } \\
\text { following a 3-second or a 6-second delay. }\end{array}$ & $\begin{array}{l}\text { Total correct } \\
\text { trials }\end{array}$ \\
\hline 18 & $\begin{array}{l}\text { (Tsai; Wang; } \\
\text { Tseng, 2012) }\end{array}$ & Inhibition & $\begin{array}{l}\text { The visuospatial } \\
\text { attention } \\
\text { paradigm }\end{array}$ & $\begin{array}{l}\text { The pupils were black-filled circles inside the eyes and were } \\
\text { centered vertically to the eyes. When cuing, the pupils were } \\
\text { just touching the right or left side of the eye (valid, invalid, } \\
\text { and catch trials) or were centered (neutral and catch trials) } \\
\text { in the eyes }\end{array}$ & $\begin{array}{l}\text { Reaction times } \\
\text { and response } \\
\text { accuracy }\end{array}$ \\
\hline 19 & $\begin{array}{l}\text { (Chen; Wilson; } \\
\text { Wu, 2012a) }\end{array}$ & Inhibition & $\begin{array}{l}\text { COVAT - Covert } \\
\text { orienting of } \\
\text { visuospatial } \\
\text { attention task }\end{array}$ & $\begin{array}{l}\text { The cueing task has been used to measure manual and eye- } \\
\text { movement reaction times to target stimuli to investigate the } \\
\text { effects of covert orienting of attention in response to different } \\
\text { cue conditions. }\end{array}$ & $\begin{array}{l}\text { Reaction times } \\
\text { and response } \\
\text { accuracy }\end{array}$ \\
\hline 20 & $\begin{array}{l}\text { (Williamset al., } \\
\text { 2013) }\end{array}$ & $\begin{array}{l}\text { Working } \\
\text { memory }\end{array}$ & $\begin{array}{l}\text { CANTAB Spatial } \\
\text { Working Memory } \\
\text { task }\end{array}$ & $\begin{array}{l}\text { It is a self-ordered searching task measuring working } \\
\text { memory for spatial stimulus. It requires participants to use } \\
\text { mnemonic information to work towards a goal }\end{array}$ & $\begin{array}{l}\text { Times and } \\
\text { response } \\
\text { accuracy }\end{array}$ \\
\hline 21 & $\begin{array}{l}\text { (Toussaint- } \\
\text { Thorin et al., } \\
\text { 2013) }\end{array}$ & $\begin{array}{l}\text { Cognitive } \\
\text { Flexibility } \\
\text { Inhibition }\end{array}$ & $\begin{array}{l}\text { Trail Making Test } \\
\text { Auditory } \\
\text { Attention/ } \\
\text { Response NEPSY } \\
\text { task }\end{array}$ & $\begin{array}{l}\text { Participants must draw a line between numbers and letters in } \\
\text { sequence, switching between the two (e.g. 1-A-2-B, etc.) } \\
\text { In the first part, the child learns to produce a response to the } \\
\text { "red » stimulus (place a red chip when the child hears the } \\
\text { word «red »). In the second part, the child must change the } \\
\text { response pattern and respond to contradicting stimuli (place } \\
\text { a red chip when hearing the word « yellow»). }\end{array}$ & $\begin{array}{l}\text { Time and Total } \\
\text { errors } \\
\text { Response } \\
\text { accuracy }\end{array}$ \\
\hline 22 & $\begin{array}{l}\text { (Rigoliet al., } \\
\text { 2013) }\end{array}$ & $\begin{array}{l}\text { Working } \\
\text { memory }\end{array}$ & $\begin{array}{l}\text { One-Back task } \\
\text { CogState Brief } \\
\text { Battery }\end{array}$ & $\begin{array}{l}\text { Determine whether the current playing card shown is the } \\
\text { same or different from the previous one or the second- } \\
\text { previous one }\end{array}$ & $\begin{array}{l}\text { Response } \\
\text { accuracy }\end{array}$ \\
\hline 23 & (Tsaiet al., 2014) & $\begin{array}{l}\text { Working } \\
\text { memory }\end{array}$ & $\begin{array}{l}\text { VSWM - } \\
\text { Visuospatial } \\
\text { Working Memory } \\
\text { Paradigm. }\end{array}$ & $\begin{array}{l}\text { The children had to compare the positions and directions of } \\
\text { the ladybugs in the rectangles; (ii) two spatial memory tasks } \\
\text { with a 3s-delay or (iii) with a 6s-delay, where the rectangles } \\
\text { and ladybugs appeared with the respective delays. }\end{array}$ & $\begin{array}{l}\text { Total correct } \\
\text { trials }\end{array}$ \\
\hline
\end{tabular}




\begin{tabular}{|c|c|c|c|c|c|}
\hline 24 & $\begin{array}{l}\text { (Giofrè; Cornoldi; } \\
\text { Schoemaker, } \\
\text { 2014) }\end{array}$ & $\begin{array}{l}\text { Working } \\
\text { memory }\end{array}$ & Corsi blocks test & $\begin{array}{l}\text { Participants were asked to recall a sequence of blocks just } \\
\text { indicated by the experimenter in the same (forward) or in } \\
\text { reverse (backward) order. }\end{array}$ & $\begin{array}{l}\text { Total correct } \\
\text { trials }\end{array}$ \\
\hline 25 & $\begin{array}{l}\text { (Prattet al., } \\
\text { 2014) }\end{array}$ & Inhibition & $\begin{array}{l}\text { The Stroop tasks } \\
\text { NEPSY } \\
\text { Knock-Tap task }\end{array}$ & $\begin{array}{l}\text { The participants should state the color of the ink in which a } \\
\text { word was printed (for example, the word "blue" printed in } \\
\text { red ink; "red" response). } \\
\text { The task requires participants to place the non-dominant } \\
\text { hand on the table and use the dominant hand to complete } \\
\text { certain actions that the researcher explained at the beginning } \\
\text { of each set of trials. }\end{array}$ & $\begin{array}{l}\text { Total correct } \\
\text { trials } \\
\text { Total correct } \\
\text { trials }\end{array}$ \\
\hline 26 & $\begin{array}{l}\text { (Rahimi- } \\
\text { Golkhandan et } \\
\text { al., 2015) }\end{array}$ & Inhibition & $\begin{array}{c}\text { Go/no-Go } \\
\text { (“cool and hot"). }\end{array}$ & $\begin{array}{l}\text { Neutral facial expressions were used for the cool task, while } \\
\text { the stimuli for the hot task were happy and fearful faces of } \\
\text { the same individuals. The task included pictures of neutral/ } \\
\text { calm, happy, and sad facial expressions of a group of men and } \\
\text { women. Children were asked to respond (by pressing the } \\
\text { spacebar) as quickly as possible to only that expression, and } \\
\text { not the other. }\end{array}$ & $\begin{array}{l}\text { Omission/ } \\
\text { Errors and } \\
\text { Reaction Time }\end{array}$ \\
\hline 27 & $\begin{array}{l}\text { (Leonard et al., } \\
\text { 2015b) }\end{array}$ & $\begin{array}{l}\text { Working } \\
\text { memory } \\
\text { Working } \\
\text { memory } \\
\text { Inhibition } \\
\text { Inhibition } \\
\text { Cognitive } \\
\text { Flexibility } \\
\text { Cognitive } \\
\text { Flexibility }\end{array}$ & $\begin{array}{c}\text { Listening recall } \\
\text { Odd-one-out } \\
\text { "Verbal Inhibition, } \\
\text { Motor Inhibition" } \\
\text { task } \\
\text { Trail Making Test/ } \\
\text { Intra-/extra- } \\
\text { dimensional } \\
\text { shift(CANTAB) }\end{array}$ & $\begin{array}{l}\text { Participants recall the last word of a sentence after making a } \\
\text { judgement as to whether the sentence was true or false, with } \\
\text { the number of sentences increasing as the task continues. } \\
\text { Participants recall the spatial location of a nonsense shape } \\
\text { after making a judgement as to which of the shapes was the } \\
\text { 'odd-one-out' } \\
\text { Participants copy a word said by the experimenter, or provide } \\
\text { another word (i.e. inhibit the copying response), depending } \\
\text { on instructions } \\
\text { Participants copy an action demonstrated by the } \\
\text { experimenter, or provide another action (i.e. inhibit the } \\
\text { copying response), depending on instructions } \\
\text { Participants have to draw a line between numbers and letters } \\
\text { in sequence, switching between the two (e.g. 1-A-2-B, etc.) } \\
\text { Participants learn a rule through initial trial and error in } \\
\text { relation to a shape and then must switch to a different rule to } \\
\text { continue achieving 'correct' answers }\end{array}$ & $\begin{array}{c}\text { Total correct } \\
\text { trials } \\
\text { Total correct } \\
\text { trials } \\
\text { Total errors } \\
\text { Total errors } \\
\text { Completion } \\
\text { time } \\
\text { switching cost } \\
\text { Total errors }\end{array}$ \\
\hline 29 & $\begin{array}{c}\text { (Rahimi- } \\
\text { Golkhandan et } \\
\text { al., 2016) } \\
\text { (Michel; Molitor; } \\
\text { Schneider, 2016) }\end{array}$ & $\begin{array}{l}\text { Inhibitory } \\
\text { control } \\
\text { Working } \\
\text { memory } \\
\text { Working } \\
\text { memory } \\
\text { Inhibitory } \\
\text { control } \\
\text { Cognitive } \\
\text { Flexibility }\end{array}$ & $\begin{array}{l}\text { Go/no-Go ('cool' } \\
\text { and 'hot'). } \\
\text { Color Span } \\
\text { Backwards Task } \\
\text { Corsi-Blocks } \\
\text { Backwards Task } \\
\text { Go/no-Go Task } \\
\text { Flanker Task }\end{array}$ & $\begin{array}{l}\text { The task included pictures of neutral/calm, happy, and sad } \\
\text { facial expressions of a group of men and women. Children } \\
\text { were asked to respond (by pressing the spacebar) as quickly } \\
\text { as possible to only that expression, and not the other. } \\
\text { A series of colored discs is presented for } 2 \text { seconds per disc. } \\
\text { After the trial, a circle with all the colored discs is presented } \\
\text { and the child must tap the correct sequence of colors (on a } \\
\text { touchscreen) in reverse order } \\
\text { There are numbers on the Corsi-blocks that only the } \\
\text { administrator can see. The administrator touches some } \\
\text { blocks and the child must touch the blocks in the inverted } \\
\text { order immediately after presentation. } \\
\text { The test requires a participant to perform an action given } \\
\text { certain stimuli (press a button - Go) and inhibit that action } \\
\text { under a different set of stimuli (not press that same button } \\
\text { - No-Go). } \\
\text { In the first part (the standard Flanker task), children have to } \\
\text { react to a red fish that appears on-screen and are told to press } \\
\text { the right or left button, according to the direction in which the } \\
\text { fish is facing. An additional task set was added to the second } \\
\text { part of this task: when appears yellow fish the child has to } \\
\text { react according to the direction of the four-flanking fish (rule } \\
\text { switching). }\end{array}$ & $\begin{array}{l}\text { Omission Errors } \\
\text { and Reaction } \\
\text { Time } \\
\text { Mean of } \\
\text { sequences } \\
\text { correctly } \\
\text { recalled } \\
\text { The longest } \\
\text { sequence } \\
\text { correctly } \\
\text { recalled. } \\
\text { Total errors } \\
\text { Accuracy and } \\
\text { mean reaction } \\
\text { time }\end{array}$ \\
\hline
\end{tabular}




\begin{tabular}{|c|c|c|c|c|c|}
\hline 30 & $\begin{array}{l}\text { Bernardi, M., } \\
\text { Leonard, H. } \\
\text { C., Hill, E. L., } \\
\text { Botting, N., \& } \\
\text { Henry, L. A. } \\
\text { (2017). }\end{array}$ & $\begin{array}{l}\text { Working } \\
\text { memory } \\
\text { Working } \\
\text { memory } \\
\text { Inhibition } \\
\text { Inhibition } \\
\text { Cognitive } \\
\text { Flexibility } \\
\text { Cognitive } \\
\text { Flexibility }\end{array}$ & $\begin{array}{c}\text { Listening recall } \\
\text { Odd-one-out } \\
\text { Verbal Inhibition, } \\
\text { Motor Inhibition” } \\
\text { task } \\
\text { Trail Making Test/ } \\
\text { Intra-/extra- } \\
\text { dimensional shift } \\
\text { (CANTAB) }\end{array}$ & $\begin{array}{l}\text { Participants recall the last word of a sentence after making a } \\
\text { judgment as to whether the sentence was true or false, with } \\
\text { the number of sentences increasing as the task continues. } \\
\text { Participants recall the spatial location of a nonsense shape } \\
\text { after making a judgment as to which of the shapes was the } \\
\text { 'odd-one-out' } \\
\text { Participants copy a word said by the experimenter, or provide } \\
\text { another word (i.e. inhibit the copying response), depending } \\
\text { on instructions } \\
\text { Participants copy an action demonstrated by the } \\
\text { experimenter, or provide another action (i.e. inhibit the } \\
\text { copying response), depending on instructions } \\
\text { Participants have to draw a line between numbers and letters } \\
\text { in sequence, switching between the two (e.g. 1-A-2-B, etc.) } \\
\text { Participants learn a rule through initial trial and error in } \\
\text { relation to a shape and then must switch to a different rule to } \\
\text { continue achieving 'correct' answers }\end{array}$ & $\begin{array}{c}\text { Total correct } \\
\text { trials } \\
\text { Total correct } \\
\text { trials } \\
\text { Total errors } \\
\text { Total errors } \\
\text { Completion } \\
\text { timeswitching } \\
\text { cost } \\
\text { Total errors }\end{array}$ \\
\hline 31 & $\begin{array}{c}\text { Alesi M., } \\
\text { Pecoraro D. } \\
\text { \&Pepi A. (2018) }\end{array}$ & $\begin{array}{l}\text { Working } \\
\text { Memory } \\
\text { Inhibitory } \\
\text { Control }\end{array}$ & $\begin{array}{c}\text { Working Memory } \\
\text { Tasks } \\
\text { Animal } \\
\text { StroopTask }\end{array}$ & $\begin{array}{l}\text { Consist on three verbal and three visuo-spatial tasks. The } \\
\text { verbal tasks were: forwards word recall, selective word recall } \\
\text { and verbal dual task and The three visuo-spatial tasks were: } \\
\text { pathway recall, selective pathway recall and visuo-spatial } \\
\text { dual task. } \\
\text { The computerized task showed images on a laptop and } \\
\text { recorded the responses and reaction times.A child was } \\
\text { required to name stimuli appearing on the screen. }\end{array}$ & $\begin{array}{c}\text { For each } \\
\text { subtestchildren } \\
\text { were given a } \\
\text { score of } 1 \text { for } \\
\text { each correct } \\
\text { performance } \\
\text { The number } \\
\text { of correct } \\
\text { responses to } \\
\text { incongruent } \\
\text { stimuli and } \\
\text { times of } \\
\text { execution for } \\
\text { each trial were } \\
\text { recorded. }\end{array}$ \\
\hline
\end{tabular}

The studies used three motor batteries to assess children motor skills; the majority of the studies $(\mathrm{n}=22)$ studies used the Movement Assessment Battery for Children-2, five studies used a McCarron Assessment of Neuromuscular Development-MAND. Some assessments (Bruininks-Oseretsky Test of MotorProficiency-2, KörperkoordinationstestFür Kinder) and interviews and questionnaires (multidisciplinary assessment of developmental dyspraxia, Motor Observation Questionnaire for Teachers, Ideomotor test questionnaire) were used with less frequency. Regarding the main results of the executive functions in children with poor motor skills or DCD compared to children with typical development the majority of the studies indicate that there is a deficit of inhibition in children with DCD, however effect size was rarely reported. Regarding, inhibition tasks 15 studies compare children with DCD with a typical development; three studies (code 13, 25, 26) found no difference between groups. One study (code 26) showed that children with DCD and with typical development had similar accuracy in Go/No-go tasks and similar errors during the task, except when the No-go stimulus was associated with conditions receiving positive reinforcement.
Regarding working memory, 15 studies compare children with DCD with children with typical development and only one study (code 14) found no difference between groups. Regarding cognitive flexibility tests, 6 studies were found comparing children with DCD or with poor motor skills with children with typical development. The results showed deficits in cognitive flexibility in children with DCD or with motor difficulty, independently of tests used, compared to control group. Table 2 presents themain results of the studies that assessed executive functions in children with poor motor skill and DCD.Insert Table 2 Using the NOS parameters, five studies implemented experimental design with very good quality; and 26 cross-sectional designs, ten with very good quality, nine with good quality, and the remaining six studies were satisfactory due to the lack of procedures adopted to control the influence of the researcher's knowledge about the sample in relation to the measurement of the outcome. However, in general, the methods of recruitment of subjects, controlling for the confounders, and outcome assessment were appropriate for all studies. 
Table 2: Motor Function tests and main results of the executive functions in children with Developmental Coordination Disorder and poor motor skill.

\begin{tabular}{|c|c|c|c|c|c|}
\hline Code & Autor & Age (year-old) & $\begin{array}{l}\text { Motor function } \\
\text { tests/cut off } * * *\end{array}$ & Groups & Main results \\
\hline $1 / 2$ & $\begin{array}{l}\text { (Mandich; Buckolz; Po- } \\
\text { latajko, 2002, 2003) }\end{array}$ & $7-12$ & $\begin{array}{l}\text { Parents ques- } \\
\text { tionnaire (from } \\
\text { authors) + } \\
\text { MABC } \leq 15^{\text {th }}\end{array}$ & $\begin{array}{l}\qquad \mathrm{DCD}=20 ; \\
\text { Control group }=20\end{array}$ & $\begin{array}{l}\text { Reaction time and errors produced with } \\
\text { the Simon task indicate that children with } \\
\text { DCD exhibit an inhibitory response dys- } \\
\text { function relative to the control group. }\end{array}$ \\
\hline 3 & (Piek et al., 2004) & $6-14$ & $\begin{aligned} & \text { MAND } \\
\geq & 80 \text { score } \\
& \left(\mathrm{NDI}^{*}\right)\end{aligned}$ & $\begin{array}{l}\text { DCD risk }=28(m=20 ; f=8) \\
\text { Control }=100(m=33 ; f=43)\end{array}$ & $\begin{array}{l}\text { There was an association between the } \\
\text { motor capacity and the task of executive } \\
\text { function that investigates working memory; } \\
\text { Motor performance does not appear to be } \\
\text { linked to inhibitory control deficits but } \\
\text { may involve temporal deficits related to the } \\
\text { cerebellum. }\end{array}$ \\
\hline 4 & (Livesey et al., 2006) & $5-6$ & MABC & DCD (15 boys, 21 girls). & $\begin{array}{l}\text { The relationship between motor perfor- } \\
\text { mance and stop-signal task performance } \\
\text { was in the expected direction but did not } \\
\text { reach significance. }\end{array}$ \\
\hline 5 & $\begin{array}{l}\text { (Alloway; archibald, } \\
\text { 2008) }\end{array}$ & $6-11$ & $\begin{array}{l}\text { MABC, Check list } \\
\text { MABC teacher }\end{array}$ & $\begin{array}{l}\text { DCD with typical language= } \\
11(\mathrm{~m}=8 ; \mathrm{f}=3) ; \mathrm{DCD}=12 \\
(\mathrm{~m}=8 \mathrm{f}=4) ; \text { Specific language } \\
\text { impairment }(\mathrm{SLI})=11(\mathrm{~m}=7 ; \\
\mathrm{f}=4)\end{array}$ & $\begin{array}{l}\text { Children with DCD had general deficits in } \\
\text { short-term verbal and visuospatial memory } \\
\text { and working memory. Children with DCD } \\
\text { with typical language skills were impaired } \\
\text { in all four areas of memory function for } \\
\text { their age level, and this pattern was also } \\
\text { found to be characteristic of a larger DCD } \\
\text { group with varied language abilities. }\end{array}$ \\
\hline 6 & (Alloway; temple, 2007) & $6-11$ & $\mathrm{MABC} \leq 5^{\text {th }}$ & $\begin{array}{l}\mathrm{DCD}=20(\mathrm{~m}=14 ; \mathrm{f}=6) ; \text { Mod- } \\
\text { erate Learning difficulties = } \\
\qquad 20(\mathrm{~m}=15 ; \mathrm{f}=5)\end{array}$ & $\begin{array}{l}\text { Children with DCD had significantly } \\
\text { lower levels than children with learning } \\
\text { difficulties in measures of short-term } \\
\text { verbal, short-term visuo-spatial memory, } \\
\text { and working memory. Children with DCD } \\
\text { appear to be impaired in all four areas } \\
\text { of memory function; in particular they } \\
\text { performed at significantly lower levels than } \\
\text { children with MLD in measures of verbal } \\
\text { short-term memory, visuo-spatial short- } \\
\text { term and working memory }\end{array}$ \\
\hline 7 & (Alloway, 2011) & $6-10$ & $\begin{array}{c}\text { Check list MABC/ } \\
\text { MABC/ NI }\end{array}$ & $\begin{array}{c}\text { DCD = 55 } \\
(\mathrm{m}=44 ; \mathrm{f}=11) ; \\
\text { Control = } 50 \\
(\mathrm{~m}=30 ; \mathrm{f}=20) ; \\
\text { TDAH }=50 \\
(\mathrm{~m}=43 ; \mathrm{f}=7)\end{array}$ & $\begin{array}{l}\text { Children with DCD performed poorly on all } \\
\text { memory tests, with particularly low scores } \\
\text { on visuospatial memory tasks. The children } \\
\text { with DCD had a depressed performance in } \\
\text { all working memory tests, with particularly } \\
\text { low scores in visuospatial memory tasks; } \\
\text { children with ADHD performed within } \\
\text { age-expected levels in short-term memory } \\
\text { but had a pervasive working memory defi- } \\
\text { cit that impacted both verbal and visuospa- } \\
\text { tial domains. }\end{array}$ \\
\hline 8 & (Alloway, 2007) & $5-11$ & $\begin{array}{l}\text { MABC + Check list } \\
\text { MABC }\end{array}$ & $\mathrm{DCD}=55(\mathrm{~m}=44 ; \mathrm{f}=11)$ & $\begin{array}{l}\text { Performance levels in verbal working } \\
\text { memory measures were slightly lower } \\
\text { in children with DCD than in the control } \\
\text { group. Deficits observed in visuospatial } \\
\text { short-term and working memory tasks } \\
\text { were significantly worse than in the verbal } \\
\text { short-term memory }\end{array}$ \\
\hline
\end{tabular}




\begin{tabular}{|c|c|c|c|c|c|}
\hline 9 & $\begin{array}{l}\text { (Alloway; Gnanathusha- } \\
\text { ran; Archibald, 2009) }\end{array}$ & $6-10$ & $\begin{array}{l}\text { Interview with } \\
\text { the child, and his } \\
\text { or her parentes } \\
\text { + neurological } \\
\text { examination }\end{array}$ & $\begin{array}{l}\text { ADHD = } 83(\mathrm{~m}=71 / \mathrm{f}=12) ; \\
\qquad \mathrm{DCD}=5 \\
(\mathrm{~m}=44 / \mathrm{f}=11) ; \\
\text { Specific language impair- } \\
\text { ment }=15(\mathrm{~m}=9 / \mathrm{f}=6) ; \\
\text { Aspeger } 10 \\
(\mathrm{~m}=8 ; \mathrm{f}=2)\end{array}$ & $\begin{array}{l}\text { Children with DCD performed poorly in } \\
\text { all areas, particularly with low scores on } \\
\text { visuospatial memory tasks. Specifically, } \\
\text { language impairments were associated } \\
\text { with selective deficits in verbal short-term } \\
\text { and working memory, whereas motor } \\
\text { impairments (DCD) were associated with } \\
\text { selective deficits in visuospatial short-term } \\
\text { and working memory. Children with atten- } \\
\text { tion problems were impaired in working } \\
\text { memory in both verbal and visuospatial } \\
\text { domains, whereas the children with AS had } \\
\text { deficits in verbal short-term memory but } \\
\text { not in any other memory component. }\end{array}$ \\
\hline 10 & (Piek et al., 2007) & $6-14$ & $\begin{array}{l}\text { MABC + Check list } \\
\text { MABC }\end{array}$ & $\begin{array}{l}\text { DCD = } 18(\mathrm{~m}=12 ; \mathrm{f}=6) ; \\
\text { Control = } 138(\mathrm{~m}=59 ; \mathrm{f}=79) \\
\text { TDAH - PI = } 20(\mathrm{~m}=6 ; \mathrm{f}=4) \\
\text { TDAH - C = } 19(\mathrm{~m}=15 ; \mathrm{f}=4)\end{array}$ & $\begin{array}{l}\text { Children with DCD were slower in both } \\
\text { trials and had greater variability in perfor- } \\
\text { mance. The DCD group was significantly } \\
\text { slower in the flexibility task. }\end{array}$ \\
\hline 11 & (Querne et al., 2008) & $8-13$ & $\mathrm{MABC} \leq 5^{\text {th }}$ & $\begin{array}{c}\text { DCD }=9(m=7 \mathrm{f}=2) ; \text { Control }= \\
10(\mathrm{~m}=7 \mathrm{f}=3)\end{array}$ & $\begin{array}{l}\text { Children with DCD obtained a similar } \\
\text { score for correct inhibitions compared to } \\
\text { the control group, but the responses were } \\
\text { slower and with more variability than in } \\
\text { the control group. }\end{array}$ \\
\hline 12 & $\left(\right.$ Tsai, 2009) ${ }^{\mathrm{n}=16}$ & $9-10$ & $\begin{array}{l}\text { MABC } \leq 5^{\text {th }} \\
\text { MAND } \\
<80 \text { score }\end{array}$ & $\begin{array}{l}\text { Control group = } 29(\mathrm{~m}=13 / \\
\mathrm{f}=16) ; \mathrm{DCD} \\
\text { Training group = 14; DCD No } \\
\text { Training group = } 14\end{array}$ & $\begin{array}{l}\text { DCD groups had the deficit of endogenous } \\
\text { visuospatial attention when compared to } \\
\text { typically developing children. This finding } \\
\text { was in line with previous research that } \\
\text { indicated a deficit of inhibitory control in } \\
\text { children with DCD. } \\
\text { This study showed a significant improve- } \\
\text { ment in motor and cognitive functions in } \\
\text { such children after the intervention of the } \\
\text { 10- week group physical activity program } \\
\text { conducted in the school setting }\end{array}$ \\
\hline 13 & (Dyck; Piek, 2010b) & 3- 14 & MABC / NI & $\begin{array}{l}\text { Language Disorder Group = } \\
30(\mathrm{~m}=22 / \mathrm{f}=8) ; \\
\text { DCD = } 20(\mathrm{~m}=13 / \mathrm{f}=7) ; \text { Poor } \\
\text { language ability = } 22(\mathrm{~m}=14 / \\
\mathrm{f}=8) ; \\
\text { Poor Motor Coordination }= \\
28(\mathrm{~m}=17 / \mathrm{f}=11)\end{array}$ & $\begin{array}{l}\text { DCD with and without language problems } \\
\text { differ significantly in measures of IQ, social } \\
\text { cognition and verbal work memory com- } \\
\text { pare to children with Language Disorder } \\
\text { and children with poor motor skills } \\
\text { No significant differences were found in the } \\
\text { inhibition between the DCD group and the } \\
\text { group with Language Disorder and children } \\
\text { with poor motor skills. }\end{array}$ \\
\hline 14 & (Michel et al., 2011) & 5- 6 & MABC- $2 \leq 10^{\text {th }}$ & $\begin{array}{l}23 \text { impaired children }(\mathrm{n}= \\
19 \text { boys) and } 23 \text { control } \\
\text { children ( } \mathrm{n}=11 \text { boys); the } \\
\text { group of older children in- } \\
\text { cluded } 24 \text { impaired children } \\
\text { ( } \mathrm{n}=15 \text { boys) and } 24 \text { control } \\
\text { children ( } \mathrm{n}=10 \text { boys) }\end{array}$ & $\begin{array}{l}\text { Inhibition and shifting performance } \\
\text { were consistently lower, compared to } \\
\text { the children without motor coordination } \\
\text { impairments } \\
\text { For the Backwards Color Recall task, there } \\
\text { were no differences between children with } \\
\text { and without motor coordination deficiency. } \\
\text { Children with low levels of motor coordi- } \\
\text { nation reacted more slowly in the tasks of } \\
\text { inhibitory control compared to the control } \\
\text { group, but not in relation to the precision } \\
\text { of the action. }\end{array}$ \\
\hline 15 & (Wuang; Su; Su, 2011) & 7- 11 & $\begin{array}{l}\text { DCDQ' } 07<55^{\text {th }} \\
\text { MABC- } 2 \leq 5^{\text {th }} \\
\text { BOT- } 2 \leq 15^{\text {th }}\end{array}$ & $\begin{array}{c}\text { DCD = } 71(\mathrm{~m}=41 ; \mathrm{f}=30) \\
\text { Control = } 70(\mathrm{~m}=37 ; \mathrm{f}=33)\end{array}$ & $\begin{array}{l}\text { Evidence of impairment in cognitive flexi- } \\
\text { bility was found in children with DCD. }\end{array}$ \\
\hline 16 & (Rigoli et al., 2012c) & $12-16$ & $\begin{array}{c}\text { MABC- } 2 \\
\text { DCD } \leq 5^{\text {th }} \\
\text { "at risk" } 6^{\text {th }} \leq 15^{\text {th }}\end{array}$ & $\begin{array}{l}\text { DCD }-93 \text { adolescents, } 38 \\
\text { girls and } 55 \text { boys }\end{array}$ & $\begin{array}{l}\text { The present study demonstrates an im- } \\
\text { portant relationship between throwing and } \\
\text { receiving skills in sports games, working } \\
\text { memory and academic performance. }\end{array}$ \\
\hline
\end{tabular}




\begin{tabular}{|c|c|c|c|c|c|}
\hline 17 & (Tsai et al., 2012) & \pm 11 & $\mathrm{MABC} \leq 5^{\text {th }}$ & $\begin{array}{c}\mathrm{N}=998 \\
\text { DCD group }-24 \\
(\mathrm{~m}=12 / \mathrm{f}=12) \\
\text { Control }=30(\mathrm{~m}=15 / \mathrm{f}=15)\end{array}$ & $\begin{array}{l}\text { Children with DCD showed no impairment } \\
\text { in spatial information processing but } \\
\text { exhibited a deficit of retrieval of geographic } \\
\text { information when performing the visuo- } \\
\text { spatial working memory task. }\end{array}$ \\
\hline 18 & $\begin{array}{l}\text { (Tsai; Wang; Tseng, } \\
\text { 2012) }\end{array}$ & $9-10$ & $\mathrm{MABC} \leq 5^{\text {th }}$ & $\begin{array}{c}\mathrm{N}=368 \\
\begin{array}{c}\text { DCD-training }(\mathrm{n}=16) \\
(\mathrm{m}=09 / \mathrm{f}=07)\end{array} \\
\begin{array}{c}\text { DCD non-training }(\mathrm{n}=14) \\
(\mathrm{m}=09 / \mathrm{f}=05)\end{array} \\
\operatorname{TD}(\mathrm{n}=21)(\mathrm{m}=11 / \mathrm{f}=10)\end{array}$ & $\begin{array}{l}\text { Compared to typical children, children with } \\
\text { DCD responded significantly more slowly } \\
\text { under all conditions of the visuospatial care } \\
\text { task, presenting a deficiency of inhibitory } \\
\text { control capacity. } \\
\text { After accounting for pre-training differ- } \\
\text { ences, on the strength of inhibitory control } \\
\text { across the post-training period indicated a } \\
\text { significant group difference in post-training } \\
\text { behavioral performance. }\end{array}$ \\
\hline 19 & $\begin{array}{l}\text { (Chen; Wilson; } \mathrm{Wu} \text {, } \\
\text { 2012a) }\end{array}$ & $9-10$ & $\mathrm{MABC} \leq 5^{\text {th }}$ & $\begin{array}{l}\text { typically developing - TD }(\mathrm{N} \\
=36) \\
\text { moderate DCD MDCD }(\mathrm{N}= \\
46)(\mathrm{m}=16 \text { e } \mathrm{f}=30) \\
\text { severe DCD }(\mathrm{N}=20)(\mathrm{m}=9 \\
\text { e } \mathrm{f}=11)\end{array}$ & $\begin{array}{l}\text { Children with DCD took significantly more } \\
\text { time on attention tasks, a problem that is } \\
\text { likely to involve inhibitory control deficits. }\end{array}$ \\
\hline 20 & (Williams et al., 2013) & 7- 12 & $\begin{array}{l}\text { MABC-2 NI } \\
\text { DCD - } 4 \text { criteria } \\
\text { DSM IV }\end{array}$ & $\begin{array}{l}\mathrm{ADHD}=14 ; \mathrm{ADHD}+\mathrm{DCD}= \\
16 ; \mathrm{DCD}=10 ; \text { control = } 18\end{array}$ & $\begin{array}{l}\text { The ADHD + DCD group was slower to com- } \\
\text { plete the task of spatial working memory } \\
\text { compared to the ADHD group. }\end{array}$ \\
\hline 21 & $\begin{array}{l}\text { (Toussaint-Thorin et al., } \\
\text { 2013) }\end{array}$ & $10-12$ & $\begin{array}{l}\text { Dyspraxia-multi- } \\
\text { disciplinary } \\
\text { Assessment pro- } \\
\text { posed } \\
\text { by Gerard and } \\
\text { Dugas. }\end{array}$ & $\begin{array}{l}\text { Dyspraxia group }=13(\mathrm{~m}=11 \text {, } \\
\mathrm{f}=2 \text { girls }) ; \\
\begin{array}{c}\text { Control group }=14(\mathrm{~m}=8 \\
\text { boys, } \mathrm{f}=6)\end{array}\end{array}$ & $\begin{array}{l}\text { Neuropsychological tests highlighted } \\
\text { planning and inhibition disorders, but no } \\
\text { impaired flexibility }\end{array}$ \\
\hline 22 & (Rigoli et al., 2013) & $5-11$ & $\begin{aligned} & \text { MAND } \\
\geq & 80 \text { score } \\
& \left(\text { NDI }^{*}\right)\end{aligned}$ & $\begin{array}{l}\text { Motor difficult }=18 \text { children } \\
\quad(11 \text { boys and } 7 \text { girls })\end{array}$ & $\begin{array}{l}\text { Children with movement difficulty, fine } \\
\text { motor skills significantly predicted later } \\
\text { One-Back accuracy and speed. One-Back ac- } \\
\text { curacy at baseline predicted better fine and } \\
\text { gross motor skills following the } 18 \text {-month } \\
\text { period. }\end{array}$ \\
\hline 23 & (Tsai et al., 2014) & $11-12$ & MABC-2NI & $\begin{array}{c}\text { DCD-training }(\mathrm{n}=20) \\
\quad(\mathrm{m}=13 / \mathrm{f}=07) ; \\
\\
\text { DCD non-training (n } 20) \\
\quad(\mathrm{m}=12 / \mathrm{f}=08) ; \\
\text { TD }(\mathrm{n}=20)(\mathrm{m}=12 / \mathrm{f}=08)\end{array}$ & $\begin{array}{l}\text { Children with DCD exhibited visuospatial } \\
\text { working memory deficits with respect to } \\
\text { behavioral performance. }\end{array}$ \\
\hline 24 & $\begin{array}{l}\text { (Giofrè; Cornoldi; Schoe- } \\
\text { maker, 2014) }\end{array}$ & 5- 11 & $\begin{array}{l}\text { MOQ-T + Ideomo- } \\
\quad \text { tor test }\end{array}$ & $\begin{array}{l}\text { DCD Group = } 23(\mathrm{~m}=11 \text { e } \\
\qquad \mathrm{f}=12) ; \\
\text { Control Group }=23(\mathrm{~m}=11 \\
\text { e } \mathrm{f}=12)\end{array}$ & $\begin{array}{l}\text { Children with DCD symptoms also had } \\
\text { deficits in visuospatial work memory, but } \\
\text { the magnitude of the difference versus the } \\
\text { control group was moderate. }\end{array}$ \\
\hline 25 & (Pratt et al., 2014) & $6-9$ & $\mathrm{MABC} \leq 5^{\text {th }}$ & $\begin{array}{l}\text { DCD }(\mathrm{N}=26)(\mathrm{m}=22 \text { e } \mathrm{f}=04) \\
\text { typically developing - TD }(\mathrm{N} \\
\quad=24)(\mathrm{m}=13 \text { e } \mathrm{f}=11)\end{array}$ & $\begin{array}{l}\text { Children with DCD had difficulties for } \\
\text { measures of inhibition of behavior and } \\
\text { planning compared to a control group, } \\
\text { although without significant correlations } \\
\text { between motor skills and performance in } \\
\text { tasks related to executive functions. }\end{array}$ \\
\hline
\end{tabular}




\begin{tabular}{|c|c|c|c|c|c|}
\hline 26 & $\begin{array}{l}\text { (Rahimi-Golkhandan et } \\
\text { al., 2015) }\end{array}$ & $7-12$ & $\begin{array}{l}\text { MAND } \\
\geq 80 \text { score } \\
\\
\left(\text { NDI }^{*}\right)\end{array}$ & $\begin{array}{l}(\mathrm{DCD}=12(\mathrm{~m}=06 \text { e } \mathrm{f}=06) \\
\text { Typically developing } \mathrm{TD}=28 \\
\qquad(\mathrm{~m}=10 \text { e } \mathrm{f}=18)\end{array}$ & $\begin{array}{l}\text { Children with DCD and typical children } \\
\text { showed comparable accuracy in Go tasks, } \\
\text { and also had similar errors, except when } \\
\text { the No-go stimulus is associated with hot } \\
\text { executive functions. }\end{array}$ \\
\hline 27 & (Leonard et al., 2015b) & 7- 11 & $\begin{array}{l}\text { Check list MABC } \\
\qquad>15^{\text {th }} \\
\text { MABC- } 2 \leq 15^{\text {th }}\end{array}$ & $\begin{array}{l}\mathrm{DCD}=23(\mathrm{~m}=16 ; \mathrm{f}=7) ; \\
\mathrm{TD}=38(\mathrm{~m}=17 ; \mathrm{f}=21) ; \\
\mathrm{MD}=30(\mathrm{~m}=17 ; \mathrm{f}=13)\end{array}$ & $\begin{array}{l}\text { The motor difficulties and DCD groups } \\
\text { scored below the control group on nonver- } \\
\text { bal tests of working memory. The DCD and } \\
\text { low motor performance groups had results } \\
\text { below the typical group of children in } \\
\text { non-verbal inhibitory control tests. There } \\
\text { were no significant differences between } \\
\text { DCD and motor difficulties groups with } \\
\text { the group of typical children in the tasks of } \\
\text { cognitive flexibility. }\end{array}$ \\
\hline 28 & $\begin{array}{c}\text { (Rahimi-Golkhandan et } \\
\text { al., 2016) }\end{array}$ & $7-12$ & $\begin{aligned} & \text { MAND } \\
\geq & 80 \text { score } \\
& \left(\mathrm{NDI}^{*}\right)\end{aligned}$ & $\begin{array}{c}36 \text { children, } \mathrm{DCD}=12 \text { (boys } \\
=4, \text { girls }=8 \\
\mathrm{TD}=24 \text { (boys }=10, \text { girls }= \\
14 ;\end{array}$ & $\begin{array}{l}\text { Children with DCD have difficulty modu- } \\
\text { lating their approach to rewarding stimuli } \\
\text { when the task demands inhibited behavior. }\end{array}$ \\
\hline 29 & $\begin{array}{l}\text { (Michel; Molitor; Schnei- } \\
\text { der, 2016) }\end{array}$ & 4- 6 & $\begin{array}{l}\text { MABC- } 2<10^{\text {th }} \\
+ \text { Körperkoordi- } \\
\text { nations-Test für } \\
\text { Kinder (KTK) }\end{array}$ & $\begin{array}{l}\text { Motor impairment } \\
\qquad \text { Group = 48; } \\
\text { Control Group = } 48\end{array}$ & $\begin{array}{l}\text { The children's executive functions dra- } \\
\text { matically improved during the one-year } \\
\text { period. Regarding to motor coordination } \\
\text { performance, half of the impaired children } \\
\text { caught up to the control children's level } \\
\text { ("remission group"), while the remaining } \\
\text { half showed no improvement ("persisting } \\
\text { group"). }\end{array}$ \\
\hline 30 & $\begin{array}{l}\text { (Bernardi, Leonard, Hill, } \\
\text { Botting, \& Henry, 2017). }\end{array}$ & $7-11$ & $\begin{array}{l}\text { MABC- } 2 \leq 15^{\text {th }} \\
\quad>15^{\text {th }}\end{array}$ & $\begin{array}{l}\mathrm{DCD}=23(\mathrm{~m}=16 ; \mathrm{f}=7) ; \\
\mathrm{TD}=38(\mathrm{~m}=17 ; \mathrm{f}=21) ; \\
\mathrm{MD}=30(\mathrm{~m}=17 ; \mathrm{f}=13)\end{array}$ & $\begin{array}{l}\text { Developmental gains in executive function } \\
\text { were similar between groups, although } \\
\text { a gap between children with poor motor } \\
\text { skills and typically developing children on } \\
\text { non verbal executive functions persisted. } \\
\text { Specifically, children with DCD performed } \\
\text { significantly more poorly than typically } \\
\text { developing children on all non verbal } \\
\text { executive function tasks and verbal fluency } \\
\text { tasks at both time points; and children } \\
\text { with motor difficulties but no diagnosis of } \\
\text { DCD showed persistent executive function } \\
\text { problems in non verbal tasks of ELWM and } \\
\text { fluency. }\end{array}$ \\
\hline 31 & $\begin{array}{c}\text { (Alesi, Pecoraro \& Pepi } \\
\text { 2018) }\end{array}$ & $3-6$ & $\begin{array}{l}\text { MABC- } 2 \leq 15^{\text {th }} \\
\quad \text { Check list MABC }^{>15^{\text {th }}}\end{array}$ & $\begin{array}{l}\text { Risk for DCD = } 18 \text { ( } 9 \text { boys } \\
\text { and } 9 \text { girls } \\
\text { TD }=18 \text { ( } 9 \text { boys and } 9 \text { girls) }\end{array}$ & $\begin{array}{l}\text { Significant differences were found between } \\
\text { children at risk for DCD and TD children on } \\
\text { cold EF tasks of visuospatial working mem- } \\
\text { ory abilities, fluency and inhibitory control, } \\
\text { but not on hot EF tasks. }\end{array}$ \\
\hline
\end{tabular}

\section{Discussion}

Executive functions play a critical role in everyday life. However, despite the obvious relevance of executive functions of children with poor motor skills and DCD, much is still unknown about individuals 'ability. We addressed this gap in the literature by conducting a systematic review to identify tests used to measure inhibition control, cognitive flexibility and working memory. A large number of tests were designed to measure inhibition in children with typical development, with poor motor skills and with DCD. A possible explanation is the fact that inhibition presents a greater representation about the other possible components in executive functions. In other words, the satisfactory development of inhibition is essential for the typical performance of the other neuropsychological abilities, such as working memory, internalization of speech, self-regulation, reconstitution, and motor control [45].Inhibition studies with children with DCD, showed 
a great variety of tests used, however the Go/No-Go test were used more often ( 3 studies) to assess a participant's capacity for sustained attention and inhibition behavior. Yet, in studies using neuroimaging to investigate the neural processes of inhibitory control of children with DCD, the Go/No-test was used [46]. Besides that, two versions, "cool Go/No-Go test" (the stimulus were faces with neutral facial expressions) and "hot Go/No-Go tests" (the stimulus were happy or fear emotions faces) were used to investigate the effects of this motivational strategy in the inhibition outcomes of children with DCD [47].

The diversity of tests used in the researches may be due to the multiple components of the executive functions and the lack of methodological agreement in the field [48]. In terms of inhibition control and working memory some tests were used to assess both functions (i.e. the trail making/updating task used by [49] while some other researchers used separate tests for these two functions [50]. It is also important to notice that the tests also differ in the extent to which they required motor skills, with tests such as the trail making/updating task requiring button pressing responses, while the Fruit Stroop task used having no motor demands [51]. Motor demands may mask the outcomes for the executive function. It would be worth mentioning that other factors such as the lack of executive function "purity" of the tests, tests interaction with age, and other aspects of inhibition could also play an important role in the test outcome [52]. For example, results indicate that there is no relation between the Stop-Signal Task with other assessment of inhibitory control in children five-to six-years-old [53]. There is an agreement that the Stop-Signal and the Day/Night Stroop tests present aspects that are very different regarding the inhibition of behavior in children with DCD; the lack of association between both tests do not pose any doubt about the validity of the tasks as a measurement of response inhibition.

Another important condition refers to tests that involve motor demands. Many tests used to assess executive functions in children require verbal, nonverbal or complex visuospatial processing, with and without motor demands. In some tests, the different demands and types of stimulus may cause secondary loss during the execution, masking the primary executive function that should be examined (motor performance or visual perception bias) and limiting the acquisition of specific information. For example, inhibition tests was often involve press a button or other kind of motor responses, therefore in this kind of tests it is important to assess the extent to which any motor difficulties or additional processing load were associated with producing the responses effects on the inhibition performance of children with DCD [54].Consequently, researchers should ensure that they account for the tests of visuospatial and motor demands when interpreting the results of children with DCD [55]. The studies review underlined wide ranging of deficits across working memory, inhibition, and cognitive flexibility in children with poor motor skills and DCD compared to children with typical development; these deficits have been previously reported [56]. Specifically, since inhibition contributed to an efficient performance of several executive function by allow the motor execution to be fluent and efficient [57], this cognitive function is essential for tasks that suddenly prevent one's self from executing an inappropriately prepared action such as riding a bicycle, playing dodge ball or football [58]. Deficits in this control process underline motor coordination problems [59]. For instance, additional taps in a motor inhibition test with children with DCD could reflect a deficit in motor control resulting in involuntary repetition of the taps of the same thumb [60].This assumption is in accordance with previous studies showing a global inhibition deficit in tasks that not requiring a motor response in DCD [61]. Consequently, clumsiness could partially result from executive functions deficit demonstrated by children with DCD resulting from early cerebral lesion [62].

Regarding working memory, the majority of studies found deficits for children with poor motor skills and DCD. Working memory is an temporary information storage system that allows the management of information, and is related to the retention of the information in the brain and to the possibility of using clues of this information to solve a problem [63].This retention capacity makes us capable of connecting unrelated elements as well as separating integrated elements [64] which support the fact that children with poor motor skills and DCD have worse results than children with typical development. These processes of disassembly and recombination of the elements are fundamental for creativity and decision making [66]. Children with DCD were significantly slower and had greater variability in performance of cognitive flexibility tests compared to the typical develop children. Cognitive flexibility requires the individuals to modulate their behavior and adapt to different requirements of a particular tests [67] and change the course of actions according to the environment' requirements [68].

This capability suggests a changein perspectives or differentiated approaches to a problem, flexibility, adjusting to the demands, rules, or priorities of each task providing the basis for higherorder functions such as planning and reasoning [68]. However, cognitive flexibility appears later in the development compared to working memory and inhibition [69], which may be the reason for a smaller number of studies found and the absence of differences between the children with DCD and with typical development. For future studies, it would be important to standardize the tests and the methods in research enrolling children with poor motor skills and DCD, to enable more precise evidences. Although, practically it may be difficult to achieve since different measures of executive function are used across countries. We also argue that there may be moderators of the associations between poor motor skills and executive functions that are unaccounted in analyses. Some studies failed to report important information such as clinical status of participants, education, economic status, medication, psychiatric disorders precluding moderator analyses on these variables. However, it is worth emphasizing that the multiple characteristics and the recognized the overlap of different comorbidities of this disorder is a great challenge [70]. Yet, to further the understanding of the association between executive function and motor skills, the definitional and measurement problems of the executive function need to be solved [71]. Without a set of clearly defined terms and measurements, it will be difficult to be more assertive about how executive function relates to children poor motor skills [72]. 


\section{References}

1. Alesi M, Pecoraro D, Pepi A (2018) Executive functions in kindergarten children at risk for developmental coordination disorder. European Journal of Special Needs Education 34(3): 285-296.

2. Alloway T (2007) Working memory, reading, and mathematical skills in children with developmental coordination disorder. J Exp Child Psychol 96(1): 20-36.

3. Alloway T (2011) A comparison of working memory profiles in children with ADHD and DCD. Child Neuropsychology 17(5): 483-494.

4. Alloway $\mathrm{T}$ (2013) Working memory across the lifespan: A crosssectional approach. Journal of Cognitive Psychology 25(1): 37-41.

5. Alloway T, Archibald L (2008) Working Memory and Learning in Children and Specific Language Impairment. J Learn Disabil 41(3): 251-262.

6. Alloway T, Gnanathusharan R, Archibald LM (2009) Working memory in children with Developmental Disorders. Journal of Learning Disabilities 42(4): 372-382.

7. Alloway T, Temple KJ (2007) A Comparison of Working Memory Skills and Learning in Children with Developmental Coordination Disorder and Moderate Learning Difficultie. Applied Cognitive Psychology, 187(2006): 165-187.

8. American Psychiatric Association. (2013). Diagnostic and statistical manual of mental disorders (DSM-5®). (A. P. Pub, Ed.). American Psychiatric Pub.

9. Asonitou K, Koutsouki D, Kourtessis T, Charitou S (2012) Motor and cognitive performance differences between children with and without developmental coordination disorder (DCD). Res Dev Disabil 33(4): 996-1005.

10. Barkley RA (1997) Behavioral Inhibition, Sustained Attention, and Executive Functions: Constructing a Unifying Theory of ADHD. Psychol Bull 121(1): 65-94.

11. Barkley RA (2001) The Executive Functions and Self-Regulation: An Evolutionary Neuropsychological Perspective. Neuropsychol Rev 11(1): 1-29.

12. Bernardi M, Leonard HC, Hill EL, Botting, N, Henry LA (2018) Executive functions in children with developmental coordination disorder: a 2year follow-up study. Dev Med Child Neurol 60(3): 306-313.

13. Biotteau M, Albaret JM, Lelong S, Chaix Y (2016) Neuropsychological status of French children with developmental dyslexia and/or developmental coordination disorder: Are both necessarily worse than one?. Child Neuropsychology 23(4): 422-441.

14. Bo J, Colbert A, Lee CM, Schaffert J, Oswald Ket. al, (2014) Examining the relationship between motor assessments and handwriting consistency in children with and without probable Developmental Coordination Disorder. Res Dev Disabil 35(9): 2035-2043.

15. Brown Lum M, Zwicker JG (2015) Brain Imaging Increases Our Understanding of Developmental Coordination Disorder: a Review of Literature and Future Directions. Current Developmental Disorders Reports 2(2): 131-140.

16. Cairney J, Rigoli D, Piek J (2013) Developmental coordination disorder and internalizing problems in children: The environmental stress hypothesis elaborated. Developmental Review 33(3): 224-238.

17. Cardoso Cde O, Dias N, Senger J, Colling APC, Seabra AG, et al. (2016) Neuropsychological stimulation of executive functions in children with typical development: A systematic review. Applied Neuropsychology: Child 0(0): 1-21.

18. Cardoso Cde O, Dias N, Senger J, Colling A PC, Seabra AG, et al. (2018) Neuropsychological stimulation of executive functions in children with typical development: A systematic review. Appl Neuropsychol Child $7(1): 61-81$.

19. Chen I, Tsai P, Hsu Y, Ma, H, Lai H (2013) Research in Developmental Disabilities Everyday memory in children with developmental coordination disorder. Res Dev Disabil 34(1): 687-694.
20. Chen WY, Wilson PH, Wu SK (2012) Deficits in the covert orienting of attention in children with Developmental Coordination Disorder: Does severity of DCD count?. Res Dev Disabil 33(5): 1516-1522.

21. Chen WY, Wilson PH, Wu SK (2012) Deficits in the covert orienting of attention in children with Developmental Coordination Disorder: Does severity of DCD count?. Res Dev Disabil 33(5): 1516-1522.

22. Coxon JP, Stinear CM, Byblow WD (2007) Selective Inhibition of Movement. J Neurophysiol 97(3): 2480-2489.

23. Diamond A (2000) Close interrelation of motor development and cognitive development and of the cerebellum and prefrontal cortex. Child Dev 71(1): 44-56.

24. Diamond A (2012) Activities and Programs That Improve Children's Executive Functions. Curr Dir Psychol Sci 21(5): 335-341.

25. Diamond A (2012) Executive Functions.

26. Diamond A (2013) Executive functions. Annual Review of Psychology 64: 135-168.

27. Diamond A, Miyake A, Friedman NP, Emerson MJ, Witzki aH, Howerter A, Diamond, A (2012) The Executive Functions and Self-Regulation: An Evolutionary Neuropsychological Perspective. Neuropsychology Review 4(1): 1-29.

28. Dyck M, Piek J (2010) How to distinguish normal from disordered children with poor language or motor skills. International Journal of Language \& Communication Disorders. Royal College of Speech \& Language Therapists 45(3): 336-344.

29. Dyck M, Piek J (2010) How to distinguish normal from disordered children with poor language or motor skills. International Journal of Language \& Communication Disorders. Royal College of Speech \& Language Therapists, 45(3), 336-344

30. Gathercole SE, Pickering SJ, Ambridge B, Wearing H (2004) The Structure of Working Memory from 4 to 15 Years of Age. Dev Psychol 40(2): 177190.

31. Giofre D, Cornoldi C, Schoemaker MM (2014) Identifying developmental coordination disorder: MOQ-T validity as a fast screening instrument based on teachers' ratings and its relationship with praxic and visuospatial working memory deficits. Res Dev Disabil 35(12): 35183525

32. Gomez A, Piazza M, Jobert A (2015) Research in Developmental Disabilities Mathematical difficulties in developmental coordination disorder: Symbolic and nonsymbolic number processing. Res Dev Disabil 43-44: 167-178.

33. Henry L (2001) How does the severity of a learning disability affect working memory performance?. Memory 9(4-6): 233-247.

34. Jelsma D, Ferguson GD, Smits Engelsman BCM, Geuze RH (2015) Shortterm motor learning of dynamic balance control in children with probable Developmental Coordination Disorder. Res Dev Disabil 38: 213-222.

35. Joshi D, Missiuna C, Hanna S, Hay J, Faught BE, et al. (2015) Relationship between BMI, waist circumference, physical activity and probable developmental coordination disorder over time. Human Movement Science 40: 237-247.

36. Koziol LF, \& Lutz JT (2013) From Movement to Thought: The Development of Executive Function. Applied Neuropsychology: Child 2(2): 104-115.

37. Leonard HC (2016) The impact of poor motor skills on perceptual, social and cognitive development: The case of developmental coordination disorder. Frontiers in Psychology 7: 31.

38. Leonard HC, Bernardi M, Hill EL, Henry L A (2015) Executive Functioning, MotorDifficulties, and Developmental Coordination Disorder. Developmental Neuropsychology 40(4): 201-215.

39. Leonard HC, Bernardi M, Hill EL, Henry LA (2015) Executive Functioning, Motor Difficulties, and Developmental Coordination Disorder Developmental Neuropsychology 40(4): 201-215. 
40. Leonard HC \& Hill EL (2015) Executive Difficulties in Developmental Coordination Disorder: Methodological Issues and Future Directions. Current Developmental Disorders Reports 2(2): 141-149.

41. Livesey D, Keen J, Rouse J, White F (2006) The relationship between measures of executive function, motor performance and externalising behaviour in 5- and 6-year-old children. Human Movement Science 25(1): 50-64

42. Malloy Diniz LF, Sedo M, Fuentes D, Leite WB (2008) Neuropsicologia das funções executivas. In C. H. P. C. \& R. M. C. D. Fuentes, L. F. MalloyDiniz (Eds.), Neuropsicologia: teoria e prática, pp. 187-206.

43. Mandich A, Buckolz E, Polatajko H (2002) On the ability of children with developmental coordination disorder (DCD) to inhibit response initiation: The simon effect. Brain and Cognition 50(1): 150-162.

44. Mandich A, Buckolz E, Polatajko H (2003) Children with developmenta coordination disorder (DCD) and their ability to disengage ongoing attentional focus: More on inhibitory function. Brain and Cognition 51(3): 346-356.

45. Michel E, Molitor S, Schneider W (2016) Differential changes in the development of motor coordination and executive functions in children with motor coordination impairments. Child Neuropsychology, p. 20-45

46. Michel E, Roethlisberger M, Neuenschwander R, Roebers CM (2011) Development of cognitive skills in children with motor coordination impairments at 12-month follow-up. Child Neuropsychology : A Journal on Normal and Abnormal Development in Childhood and Adolescence 17(2): 151-172.

47. Miyake A, Friedman NP (2012) The Nature and Organization of Individual Differences in Executive Functions: Four General Conclusions. Current Directions in Psychological Science 21(1): 8-14.

48. Miyake A, Friedman NP, Emerson M J, Witzki AH, Howerter A, et al. (2000) The unity and diversity of executive functions and their contributions to complex "Frontal Lobe" tasks: a latent variable analysis. Cognitive Psychology 41(1): 49-100.

49. Moher D, Liberati A, Tetzlaff J, Altman DG (2009) Preferred Reporting Items for Systematic Reviews and Meta-Analyses: The PRISMA Statement. PLoS Med 6(7).

50. Nelson HE (1976) A Modified Card Sorting Test Sensitive to Frontal Lobe Defects. Cortex 12(4): 313-324.

51. Nosek BA, Banaji MR (2001) The Go / No-Go Association Task. Social Cognition 19(6): 625-666.

52. Piek JP, Dyck M, Francis M, Conwell A (2007) Working memory, processing speed, and set-shifting in children with developmental coordination disorder hyperactivity disorder. Dev Med Child Neurol 49(9): 678-683.

53. Piek JP, Dyck MJ, Nieman A, Anderson M, Hay D, et al. (2004) The relationship between motor coordination, executive functioning and attention in school aged children. Archives of Clinical Neuropsychology 19(8): 1063-1076.

54. Pratt ML, Leonard HC, Adeyinka H, Hill EL (2014) The effect of motor load on planning and inhibition in developmental coordination disorder. Research in Developmental Disabilities 35(7): 1579-1587.

55. Pureza JR, Jacobsen GM, Grassi Oliveira R, Fonseca RP (2011) Relationships between executive functions tasks in late childhood. Psychology and Neuroscience 4(3): 369-376.

56. Querne L, Berquin P, Vernier Hauvette MP, Fall S, Deltour L, et al. (2008) Dysfunction of the attentional brain network in children with Developmental Coordination Disorder: A fMRI study. Brain Research 1244(9): 89-102.

57. Rahimi Golkhandan S, Piek JP, Steenbergen B, Wilson PH (2014) Hot executive function in children with Developmental Coordination Disorder: Evidence for heightened sensitivity to immediate reward. Cognitive Development 32: 23-37.
58. Rahimi Golkhandan S, Steenbergen B, Piek JP, Caeyenberghs K, Wilson PH (2016) Revealing hot executive function in children with motor coordination problems: What's the go? Brain and Cognition 106: 55-64.

59. Rahimi Golkhandan S, Steenbergen B, Piek J, Wilson PH (2015) Reprint of "Deficits of hot executive function in developmental coordination disorder: Sensitivity to positive social cues." Human Movement Science 42: 352-367.

60. Rigoli D, Piek JP, Kane R, Oosterlaan J (2012) Motor coordination, working memory, and academic achievement in a normative adolescent sample: Testing a mediation model. Archives of Clinical Neuropsychology 27(7): 766-780.

61. Rigoli D, Piek JP, Kane R, Oosterlaan J (2012) Motor coordination, working memory , and academic achievement in a normative adolescent sample : Testing a mediation model. Archives of Clinical Neuropsychology 27(7): 766-780.

62. Rigoli D, Piek JP, Kane R, Whillier A, Baxter C, et al. (2013) An 18-month follow-up investigation of motor coordination and working memory in primary school children. Human Movement Science 32(5): 1116-1126.

63. Roebers CM, Rothlisberger M, Neuenschwander R, Cimeli P, Michel E, et al. (2014). The relation between cognitive and motor performance and their relevance for children's transition to school: A latent variable approach. Human Movement Science 33(1): 284-297.

64. Takahashi N, Hashizume M (2014) A systematic review of the influence of occupational organophosphate pesticides exposure on neurological impairment. BMJ Open 4(6): 4798-798.

65. Toussaint Thorin M, Marchal F, Benkhaled O, Pradat Diehl P, Boyer FC, et al. (2013). Executive functions of children with developmental dyspraxia: Assessment combining neuropsychological and ecological tests. Annals of Physical and Rehabilitation Medicine 56(4): 268-287.

66. Tsai CL (2009) The effectiveness of exercise intervention on inhibitory control in children with developmental coordination disorder: Using a visuospatial attention paradigm as a model. Research in Developmental Disabilities 30(6): 1268-1280.

67. Tsai CL, Chang YK, Chen FC, Hung TM, Pan CY, et al. (2014) Effects of Cardiorespiratory Fitness Enhancement on Deficits in Visuospatial Working Memory in Children with Developmental Coordination Disorder: A Cognitive Electrophysiological Study. Archives of Clinical Neuropsychology 29(2): 173-185.

68. Tsai CL, Chang YK, Hung TM, Tseng YT, Chen TC (2012) The neurophysiological performance of visuospatial working memory in children with developmental coordination disorder. Developmental Medicine \& Child Neurology 54(12): 1114-1120.

69. Tsai CL, Pan CY, Chang YK, Wang CH, Tseng K Da (2010) Deficits of visuospatial attention with reflexive orienting induced by eye-gazed cues in children with developmental coordination disorder in the lower extremities: An event-related potential study. Research in Developmental Disabilities 31(3): 642-655.

70. Tsai CL, Wang CH, Tseng YT (2012) Effects of exercise intervention on event-related potential and task performance indices of attention networks in children with developmental coordination disorder. Brain and Cognition 79(1): 12-22.

71. Valentini NC, Clark J, Whitall J (2014) Developmental co-ordination disorder in socially disadvantaged Brazilian children. Child: Care, Health and Development 41(6): 970-979.

72. Valentini NC, Coutinho MC, Pansera SM, Santos VAP dos, Vieira JLL, et al. (2012) Prevalence of motor deficits and developmental coordination disorders in children from South Brazil. Revista Paulista de Pediatria 30(3): 377-384

73. Williams J, Omizzolo C, Galea MP, Vance A (2013) Motor imagery skills of children with Attention Deficit Hyperactivity Disorder and Developmental Coordination Disorder. Human Movement Science 32(1): 121-135. 
74. Wilson PH, Rahimi Golkhandan S, Ruddock S, Piek J, Sugden DA et al. (2015) Development of executive function in children with Developmental Coordination Disorder (DCD): A two year longitudinal investigation. Developmental Medicine \& Child Neurology 57: 1-26.

75. Wilson PH, Ruddock S, Smits Engelsman BCM, Polatajko H, Blank R (2012) Understanding performance deficits in developmental coordination disorder: A meta-analysis of recent research. Developmental Medicine and Child Neurology 55(3): 20-23.

76. Wuang YP, Su CY, Su JH (2011) Wisconsin Card Sorting Test performance in children with developmental coordination disorder. Research in Developmental Disabilities 32(5): 1669-1676.
77.Zwicker JG, Missiuna C, Harris SR, Boyd LA (2012) Developmental coordination disorder: A review and update. European Journal of Paediatric Neurology 16(6): 573-581.

78. Alesi M, Pecoraro D, Pepi A (2019) Executive functions in kindergarten children at risk for developmental coordination disorder. European Journal of Special Needs Education 34(3): 285-296.

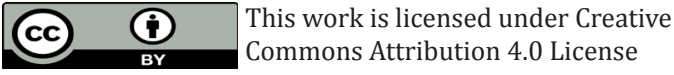

To Submit Your Article Click Here: Submit Article

DOI: $10.32474 /$ PAPN.2019.02.000138

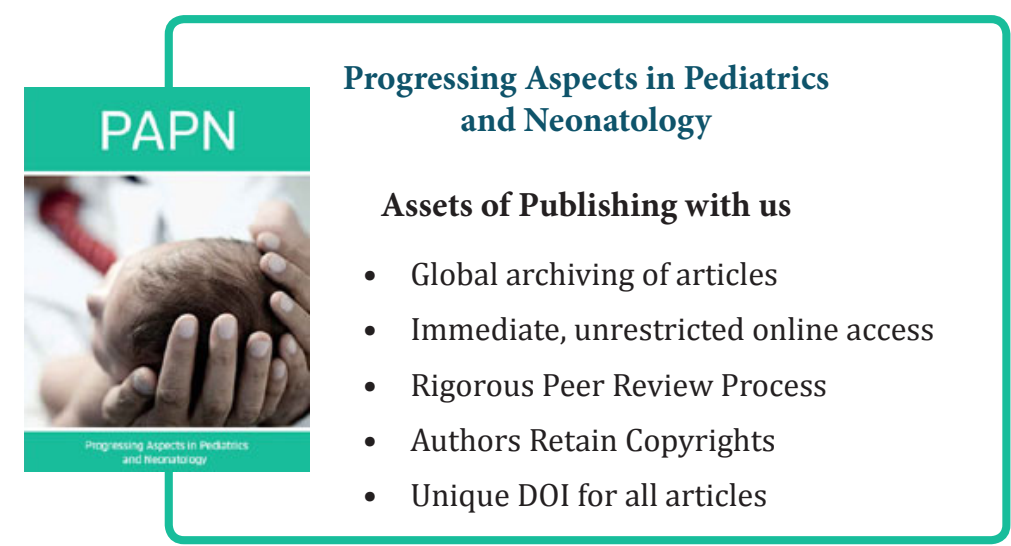

